Original Paper http://ajol.info/index.php/ijbcs http://indexmedicus.afro.who.int

\title{
Impact of Jatropha plantation on soil chemical and biological properties in the South Sudanian region in Burkina Faso
}

\author{
Pascal BAZONGO ${ }^{1,2 *}$, Karim TRAORE ${ }^{1}$, Kadidia B. SANON ${ }^{3}$, Barthelemy YELEMOU ${ }^{4}$, \\ Ouola TRAORE ${ }^{1}$, Bismarck H. NACRO ${ }^{2}$, Bernard BACYE ${ }^{2}$, Mahamadi BELEM ${ }^{2}$, \\ Mamadou TRAORE ${ }^{2}$, Victor HIEN ${ }^{5}$ and Michel P. SEDEGO ${ }^{5}$
}

\footnotetext{
${ }^{1}$ Institut de l'Environnement et de Recherches Agricoles (INERA), Département Gestion des Ressources Naturelles et Système de Production, INERA-Farako-Ba, Laboratoire Sol Eau Plante, BP 910 Bobo-Dioulasso, Burkina Faso.

${ }^{2}$ Université Polytechnique de Bobo, Ecole Doctorale, Sciences Naturelles et Agronomie 01 BP. 1091 BoboDioulasso 01 Burkina Faso.

${ }^{3}$ Laboratoire de Microbiologie, INERA/DPF, 03 BP 7047 Ouagadougou 03, Burkina Faso.

${ }^{4}$ Institut de l'Environnement et de Recherches Agricoles (INERA), Département Gestion des Ressources Naturelles et Système de Production, INERA-Saria, BP 10 Koudougou, Burkina Faso.

${ }^{5}$ Institut de l'Environnement et de Recherches Agricoles (INERA), Département Gestion des Ressources Naturelles et Système de Production, INERA-Kamboinsé, Faso Laboratoire Sol-Eau-Plante, 01 BP 476 Ouagadougou 01, Burkina Faso.

*Corresponding author, E-mail: bazpasco@yahoo.fr; 01 BP. 1091 Bobo-Dioulasso 01 Burkina Faso.
}

\author{
AKNOWLEDGMENTS \\ The authors are grateful to African Union and to European Union through the "10 ${ }^{\text {th }}$ European \\ fund for Development" and the program of subvention to the research of African Union \\ [HRST/ST/AURG/CALL1/2011], for financial support in Burkina Faso .
}

\begin{abstract}
In Burkina Faso, about 100,000 ha of Jatropha were planted during the past 10 years. Despite this enthusiasm, few results exist on the impact of the plant on soil properties. This study contributes to better knowledge of Jatropha farming and was carried out in 2013 with Jatropha farmers in Torokoro and Tin villages in the south Sudanian zone of Burkina Faso (rainfall 900-1200 mm). Data collection plots of $400 \mathrm{~m}^{2}$ repeated 3 times were installed in 3 farmers' fields in each village. Soil samples were collected at 3 distances $(\mathrm{D} 0=$ under the crown, $\mathrm{D} 1=1 \mathrm{~m}$ and $\mathrm{D} 2=2 \mathrm{~m}$ ) from the Jatropha trees lines and in a fallow as a control sample for each field. The results showed significant differences between distances for soil $\mathrm{pH}$. Soil nutrients increase with distance from the crown (from 9.33\% to 12.20\%) for available phosphorus in Torokoro-6 years and decrease from $22.45 \%$ to $23.71 \%$ in Torokoro-2 years). Soil respiration and microbial biomass decreases also with distance. The density of spores of mycorrhizal fungi is higher for the control soils (14.64\%) and it decreases from crown to $2 \mathrm{~m}$ (from $2.22 \%$ to $9.53 \%$ in Tin-2 years). The study showed the contribution of Jatropha trees on soil fertility improvement.
\end{abstract}

(C) 2015 International Formulae Group. All rights reserved.

Keywords: Jatropha, soil biology, microbial biomass, carbon, nitrogen, Burkina Faso. 


\section{INTRODUCTION}

Jatropha curcas L. is formerly used as a fence to protect the gardens against human and animal's penetration. Today, the plant has expanded across the world because of its multiple uses. Jatropha has emerged as a promising plant for biofuel production because its grains contain $30-40 \%$ oil with a fatty acid similar to the edible oils (Paramathma et al., 2007). Jatropha is a potential source of income for poor farmers with possible significant reduction in the oil bill (Blin et al., 2008). Indeed, the main advantage of Jatropha is its ability to grow in semi-arid lands where traditional agriculture is dedicated to food (Lottman, 2008). The fact that the plant grows without much requirement and grows well in tropical countries, arid, semi - arid and humid, it removes any risk of competition with other crops (Low et al., 2007; Endelevu, 2009). According to Laviola et al. (2008), Sreedevi et al. (2009) and Achten (2010a), Jatropha can help restoring the soil through its leaves and fruit losses. In Burkina Faso, the production of Jatropha has developed over the past 10 years through several development projects (Traoré, 2009; Halensleben, 2011). Approximately 100,000 ha of land were planted by farmers with Jatropha (Sanou, 2010). The southern Sudanian region of Burkina Faso (rainfall 900-1200 mm), with more than 10,000 hectares planted by 200 farmers groups (Traoré, 2009) is a pioneer site that have benefited from the support from many NGOs. However, little scientific works have been conducted on plants in Burkina Faso (Openshaw, 2000; Compete, 2008; Baumert, 2010). Yet, many studies have shown the positive effects of the plant on soil properties (Brittaine et al., 2010; FAO, 2010; Rubens et al., 2010). Due to its ability to produce some toxic substance (Paramathma et al., 2007), can't Jatropha influence the chemical and biological properties of soil? We hypothesized that Jatropha contributes to the improvement of soil chemical and biological properties. This contribution varies depending on the age of the plantation and the soil chemical properties and climate conditions.

\section{MATERIALS AND METHODS \\ Study sites}

The study was carried out in two villages in the south- Sudanian zone of Burkina Faso: Tin and Torokoro during the rainy season in 2013. Annual rainfall in the area is between 900 and $1200 \mathrm{~mm}$ (Traoré, 2009), with a rainy season from 4 to 5 months. These sites were selected because of the support from Jatropha promoters. In addition, these two sites are located on a south- west transect with different soil conditions.

\section{Torokoro location}

Torokoro site is located at $14 \mathrm{~km}$ from Mangodara, in the Cascade region and the province of Comoe. The GPS coordinates are: longitude $4^{\circ} 20^{\prime}$ West and $9^{\circ} 59^{\prime}$ north latitude.

The climate is south Sudanian with monthly rainfall between 50 and $300 \mathrm{~mm}$ during the rainy season (Figure 1). The average temperature is $27-28{ }^{\circ} \mathrm{C}$ and cropping period of 5 to 6 months. The vegetation is savanna and woodlands (Youl, 2009). Site soils are leached ferruginous tropical concretions (Youl, 2009). They have a siltysandy texture to sandy clay surface and silty clay loam to sandy clay up induration (Youl, 2009).

\section{Tin location}

Tin site is located $15 \mathrm{~km}$ from Orodara, in the region of Hauts-Bassins and in Kénédougou province. The GPS coordinates of the location are: longitude $04^{\circ} 97^{\prime}$ West and latitude $11^{\circ} 08^{\prime}$ North. The climate is south Sudanian with annual rainfall between 40 and $450 \mathrm{~mm}$ during the rainy season (Figure 2). 
Average temperatures range between $24^{\circ}$ and $30{ }^{\circ} \mathrm{C}$. The vegetation is savanna and woodland vegetation in the area (Béné et al., 2014). Soils are ferruginous (Béné et al., 2014). These soils have clay-sandy texture; or silty clay with varying fertility. These soils are deep soils (> $125 \mathrm{~cm}$ ), red and homogeneous.

\section{Sites and producers selection and age of the plantations}

The two sites are selected test sites of INERA (Institute of Environment and Agricultural Research) to conduct research on Jatropha (Traoré, 2009). The main feature of the two sites is that producers have agroforestry tradition with the integration of the fruit trees with seasonal plants (Youl, 2009). Experimenters' producers have been selected on their experience in the cultivation of Jatropha. Plantations of 2 years and 6 years were selected for conducting the evaluation because already in production and different enough to assess the effects of the hedge on soil properties.

\section{Device for data collection}

At each location, 6 Jatropha fields were selected (3 plantations of 2 years old and 3 plantations of 6 years old). In each field, a data collection design was installed and consisted of a plot of $400 \mathrm{~m}^{2}(20 \mathrm{~m} \times 20 \mathrm{~m})$ including one hedge of Jatropha and repeated 3 times. The factor studied was soil sampling distance from the hedge of Jatropha D0 = under the crown, D1 $=1 \mathrm{~m}$ from the crown and D2 $=2 \mathrm{~m}$ from the crown of Jatropha.

\section{Collection and preparation of soil samples}

For each distance from the crown, three samples were taken at three points and mixed to make a composite sample. All samples were taken at horizon $0-20 \mathrm{~cm}$ as most of the microbial biomass and soil biological activity is concentrated at this depth according to Girard et al. (2011). A control sample was taken from the adjacent field without Jatropha. The collected samples were then dried in the open air, ground and sieved to 2 $\mathrm{mm}$ for analysis in laboratory.

\section{Laboratory analysis}

Laboratory analysis was focused on the following chemical parameters: $\mathrm{pH}_{\mathrm{H} 20}$ and $\mathrm{pH}_{\mathrm{KCl}}$, organic carbon, total nitrogen and available phosphorus. The biological parameters determined were: microbial activity, microbial biomass and biomass of mycorrhizal fungal spores from the soil.

\section{Chemical parameters}

The $\mathrm{pH}_{\mathrm{H} 20}$ was measured using an electronic $\mathrm{pH}$ meter on a distilled earth suspension ratio of $1 / 2.5$ (BUNASOLS, 1986). Walkley and Black method (1934) was used for the determination of organic carbon. The Total nitrogen was determined by the Kjeldahl method (Hillebrand et al., 1953). Available phosphorus was assayed according to Bray 1 method (Dickman et al., 1940).

Overall biological activity of the soil

The overall soil biological activity (C$\mathrm{CO}_{2}$ released) was evaluated by the respirometric test method (Thiombiano et al., 1999). This test is to measure the carbon dioxide given off during the processing of organic matter by microorganisms. The soil samples were first dried in the open air and in the shade, and sieved to $2 \mathrm{~mm}$. Thereafter, $100 \mathrm{~g}$ of soil moistened to $2 / 3$ of its field capacity were introduced in a glass jar of 11 . In the jar, a beaker containing $20 \mathrm{ml}$ of $0.1 \mathrm{~N}$ $\mathrm{NaOH}$ was allowed to trap the evolved $\mathrm{CO}_{2}$ and a container containing water was used to maintain the humidity were placed. The sealed jar was incubated at the temperature of $30{ }^{\circ} \mathrm{C}$. The $\mathrm{CO}_{2}$ was measured by colorimetry on daily basis for three weeks, with the $0.1 \mathrm{~N}$ hydrochloric acid in the presence of 4 drops of phenolphthalein. At the time of the assay to prevent the fixation of atmospheric $\mathrm{CO}_{2}$ by soda exposed in the beaker, $4 \mathrm{ml}$ of 
dehydrated barium chloride $\left(\mathrm{BaCl}_{2}, 2 \mathrm{H}_{2} \mathrm{O}\right)$ were added to the solution. The amount of $\mathrm{C}$ $\mathrm{CO}_{2}$ (in $\mathrm{mg}$ per $100 \mathrm{~g}$ of soil) released was determined according to the following formula:

C- $\mathrm{CO}_{2}(\mathrm{mg} .100 \mathrm{~g}-1)=(\mathrm{V}$ control - V sample) $* 2.2$

Vcontrol = volume of $\mathrm{HCl}$ used for control jars;

Vsample $=$ volume of $\mathrm{HCl}$ used for jars containing soil samples;

2.2 = constant mineralization rate.

\section{Microbial biomass}

The fumigation - incubation technique (Wu et al., 1990) was used for the determination of the microbial biomass. Thus, $100 \mathrm{~g}$ of soil sieved to $2 \mathrm{~mm}$ in diameter, previously dried in the open air and in the dark, were wetted to $2 / 3$ of the maximum holding capacity in water and introduced into a glass jar of 1 liter in order to boost the activation of biological activity. These soils were then treated with chloroform vapor for removing microorganisms that they contain. Samples were incubated in an oven for 14 days at $28{ }^{\circ} \mathrm{C}$. The carbon dioxide produced by the bodies of microorganisms was trapped with $0.1 \mathrm{~N}$ sodium hydroxide solution and determined by titration with $0.1 \mathrm{~N}$ hydrochloric acid. Microbial biomass was estimated using the formula used by Chaussod et al. (1986).

$\mathrm{BM}(\mathrm{mg})=(\mathrm{F}(0-7))-(\mathrm{F}(7-14)) / \mathrm{Kc}$ where $F(0-7)$ and $F(7-14)$ respectively represents the amount of $\mathrm{CO}_{2}$ released on day 7 and 14th day;

$\mathrm{BM}=$ microbial biomass in $\mathrm{mg}$ per 100 $\mathrm{g}$ of soil;

$\mathrm{Kc}=0.41$ corresponds to the proportionality coefficient representing the mineralizable $\mathrm{CO}_{2}$ fraction of biomass carbon.

Arbuscular Mycorrhizal spores density

Like most tropical plants, Jatropha lives in symbiosis with Arbuscular Mycorrhizal Fungi (AMF) (Leye et al., 2009). The usual method of estimation of the presence of AMF involves the numeration of the spores. The communities of these fungi present in a soil can be estimated in terms of number of species and abundance of each of them in the community. Estimation of AMF abundance can be made by direct observation of the number of spores in the soil (Brundrett et al., 1994). The influence of Jatropha on the abundance of AMF spores was evaluated. The wet sieving method developed by Gerdemann et al. (1963) was used to extract the spores from $100 \mathrm{~g}$ of dry soil for each sample, with three replicates per sample. Spores are then counted under a binocular microscope to assess the effect of the Jatropha plant on AMF density of the underlying soil.

\section{Statistical analysis}

The collected data were entered into Excel version 2007 and analyzed with XLSTAT- PRO software version 7.5.2 (2012). The means were compared using the Newman-Keuls test at probability level $\mathrm{p}=$ $5 \%$. Pearson correlation was used to determine the relationships between the variables.

\section{RESULTS}

\section{Chemical properties of soils under Jatropha plantation \\ Torokoro Plantations}

The results show significant difference between the distances for soil $\mathrm{pH}$ (Table 1). Soil pH under Jatropha is significantly higher compared to the control. There is difference in soil $\mathrm{pH}$ between plantations of 2 years and 6 years. The results show higher organic matter content for young plantations (2 years) than for older ones (6 years) and the value decreases with distance from the crown. From under the crown to D1 and D2, the organic matter decreased from $22.43 \%$ to $23.71 \%$ for the 2 years plantation. The same trend is observed for the 6 years plantation. Soil 
nitrogen content is very low for all distances. Available phosphorus content in the soil, decrease from the crown towards out of the crown, from D1 $(9.33 \%)$ to D2 $(12.20 \%)$ compared to the control in Torokoro. This observation is similar to Tin for plantations of 2 years and 6 years (Table 1 ).

\section{Tin plantations}

Soil chemical parameters are comparable to those of Torokoro location (Table 2). The levels of nutrients are higher for the plantation of 6 years than for the plantation of 2 years. Soils $\mathrm{pH}$ in Tin is closed to neutral, these soils are suitable for grain production. The organic matter content is lower for the plantation of 2 years compared to the one of 6 years which is the opposite situation found for the site of Torokoro. A higher organic matter accumulation was noticed for 6 years plantations. For both ages, there is an accumulation of organic matter under the crown than outside $(16.5 \%)$. The control plot shows a higher organic matter content $(15.46 \%)$ compared to plots under Jatropha. The nitrogen content is low for the 2 years plantations than for the 6 years one. There is a tendency of higher nitrogen under the crown.

\section{Soil biological properties in Jatropha plantations \\ Quantities of $\mathrm{CO}_{2}$ released}

The Jatropha trees presence affected the amount of $\mathrm{C}-\mathrm{CO}_{2}$ released (Figures 3 to 6). The quantities of $\mathrm{C}-\mathrm{CO}_{2}$ decreased up to day 7 and then increased between day 8 and 10 and decrease to almost 0 at day 21. The lower quantities of $\mathrm{C}-\mathrm{CO}_{2}$ are observed for the control soils.

The results show the same trends for plantations of 2 and 6 years (Figures 3 to 6). However, the quantities at beginning are lower for the 2 years plantation than the 6 years one. The quantities of $\mathrm{C}-\mathrm{CO}_{2}$ are higher under the crown than outside.

Accumulated quantities of $\mathrm{C}$ - $\mathrm{CO}_{2}$ during the 21 days

The data showed comparable microbial biomass at different locations. At Torokoro location, the results show significantly higher $\mathrm{C}$ - $\mathrm{CO}_{2}$ accumulation for the 6 years plantations than for the 2 years ones (Figure 7). The results are comparable for different distances from the crown and the lowest C$\mathrm{CO}_{2}$ accumulation was observed in the control soil for the 6 years plantations. The opposite situation was found for the 2 years plantations (the highest $\mathrm{C}-\mathrm{CO}_{2}$ accumulation was found in the control plot). At Tin location (Figure 8), the $\mathrm{C}-\mathrm{CO}_{2}$ accumulation values are higher than those found for Torokoro location. The trend of the data is similar to Torokoro. The lowest $\mathrm{C}-\mathrm{CO}_{2}$ accumulation was observed in the control samples. $\mathrm{C}-\mathrm{CO}_{2}$ accumulation is higher for the 6 years plantation than for the 2 years ones.

\section{Microbial biomass in the fields of Jatropha}

The microbial biomass shows highly significant difference at Torokoro and Tin locations (Table 3). The results show a decreasing microbial biomass from the crown to outside. Highly significant differences were observed between the control and the other treatments in both site and for both age of plantations. Moreover, in these 6 years plantations the microbial biomass is particularly higher (approximately 4 times higher) compared to the three treatments.

\section{Arbuscular Mycorrhizal Fungal (AMF) spores density}

The richness of the soil in mycorrhizal fungi spores shows variations according to the sampling distance (Table 4). In Torokoro, the number of fungal spores decreases from under the crown to outside with a significant difference between distances for the old plantation. From under the crown to D1 and 
D2, the density of spores decreased from $0.30 \%$ to $+3.85 \%$ for the 2 years plantation. The same trend is observed for Tin. Spores density is significantly higher under the crown and at D1 (838.66) than D2 (784.44) for the plantations of 6 years. However, the density of spores remains high for the control (979.33) in all plantations.

Correlations between chemical and biological properties of soils in Jatropha fields

The results of the Pearson correlation model showed positive correlations between some chemical and biological parameters of soils. At Torokoro (Table 5), high positive correlations were found between microbial biomass and chemical properties $(\mathrm{pH}, \mathrm{N}, \mathrm{C}$,
OM). Positive and high correlations (0.778) were observed between the release of $\mathrm{C}-\mathrm{CO}_{2}$ and available $\mathrm{P}$. The same correlation (0.989) is observed between the number of spores and available P (Figure 9). The other variables are negatively correlated to microbial biomass, except $\mathrm{C} / \mathrm{N}$.

At Tin, results show a strong correlation between microbial biomass and soil chemical properties on the one hand, and between $\mathrm{C}$ $\mathrm{CO}_{2}$ accumulation and chemical properties on the other hand instead of available $\mathrm{P}$ (Table 6). Moreover, on this site, the correlation is very strong between available $P$ and the number of spores (Figure 10) while this factor is negatively correlated with other soil chemical properties.

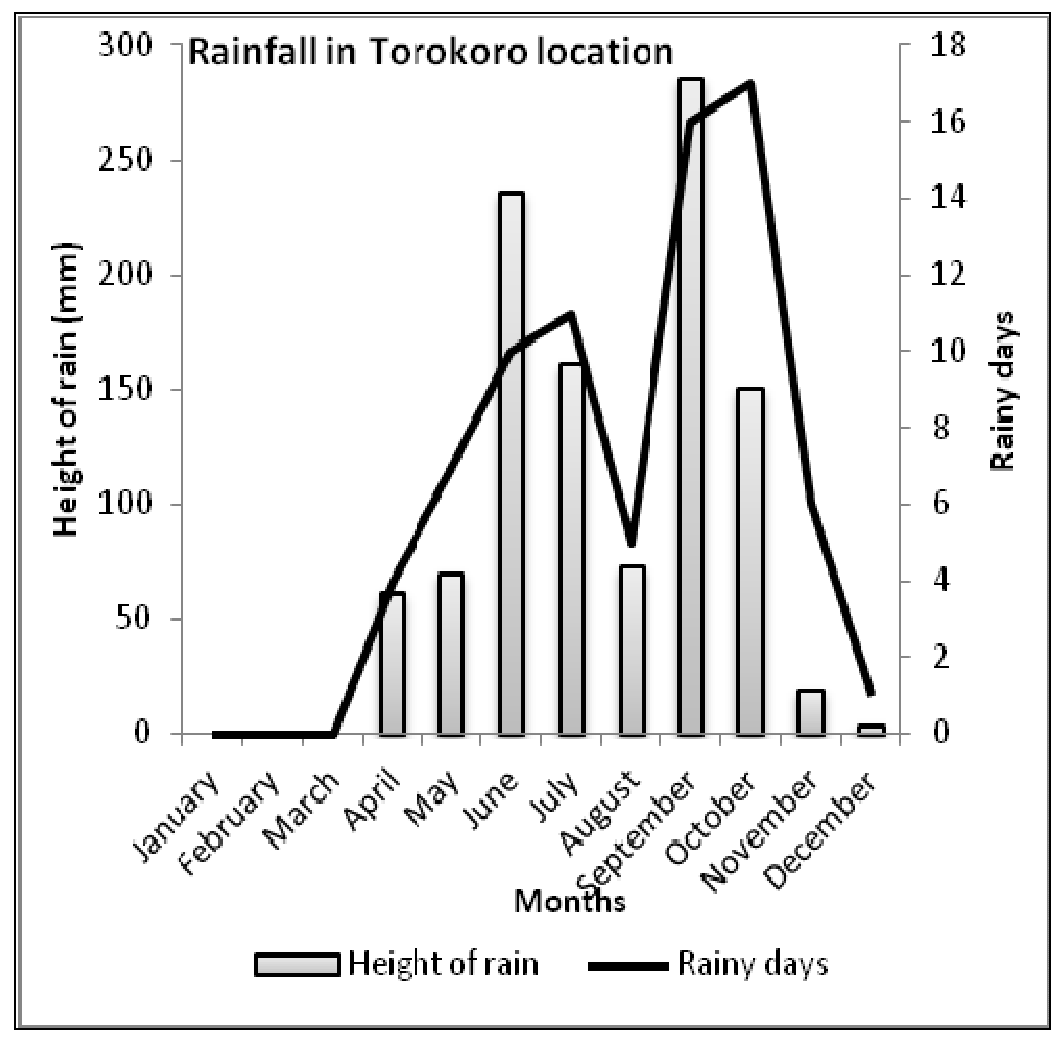

Figure 1: Rainfall in Torokoro site in 2013. DPASA of Comoe, 2013. 


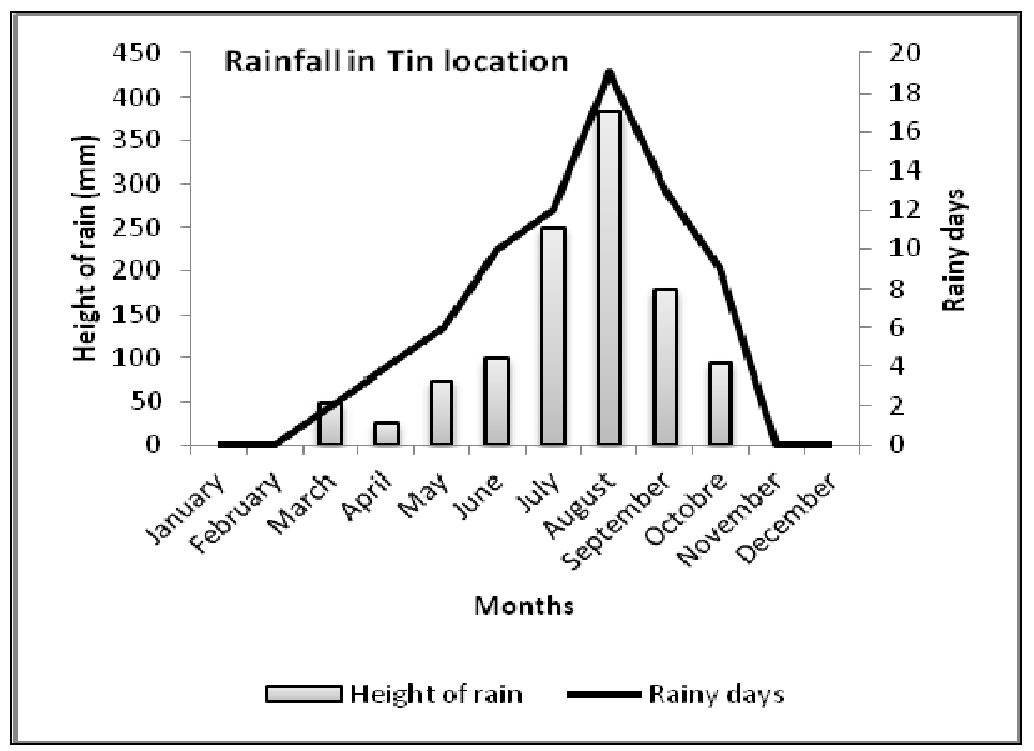

Figure 2: Rainfall in Tin site in 2013. DPASA of Kenedougou, 2013.

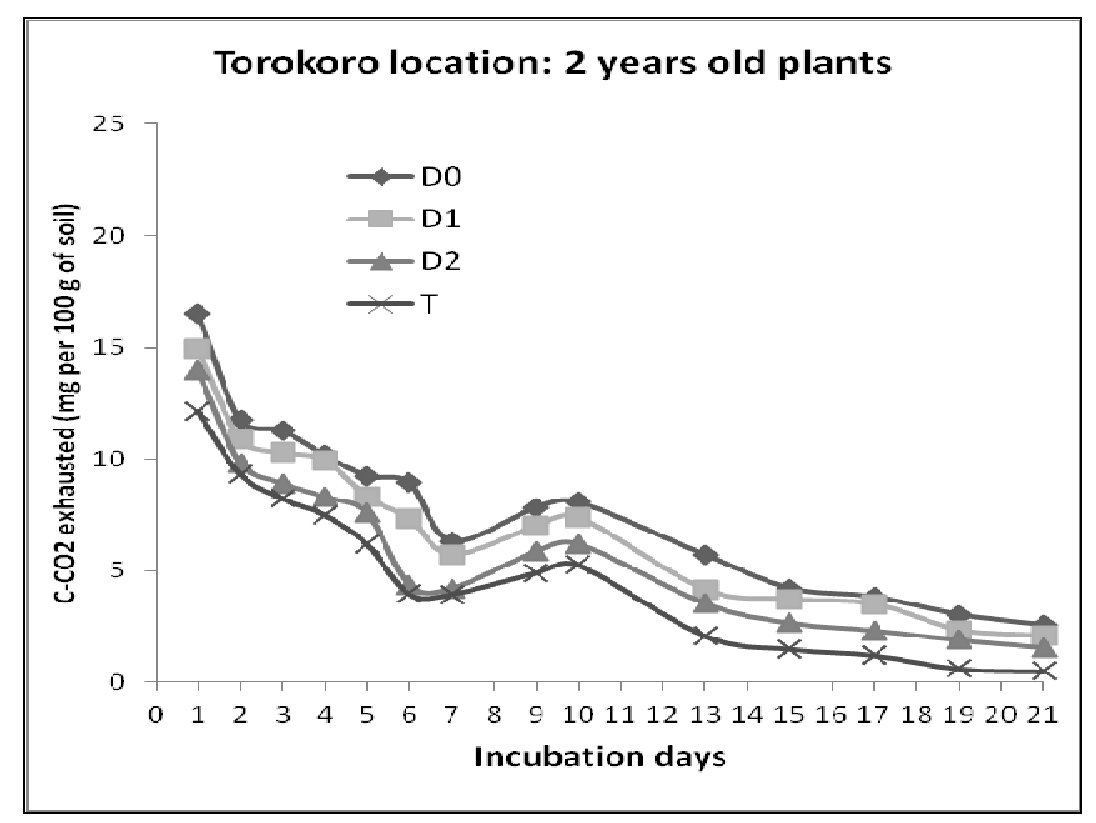

Figure 3: $\mathrm{CO}_{2}$ evolution during 21 days in Torokoro (Plantation 2 years). D0= under the crown, $\mathrm{D} 1=1 \mathrm{~m}$ from the crown of the tree, $\mathrm{T}=$ control (field without Jatropha). 


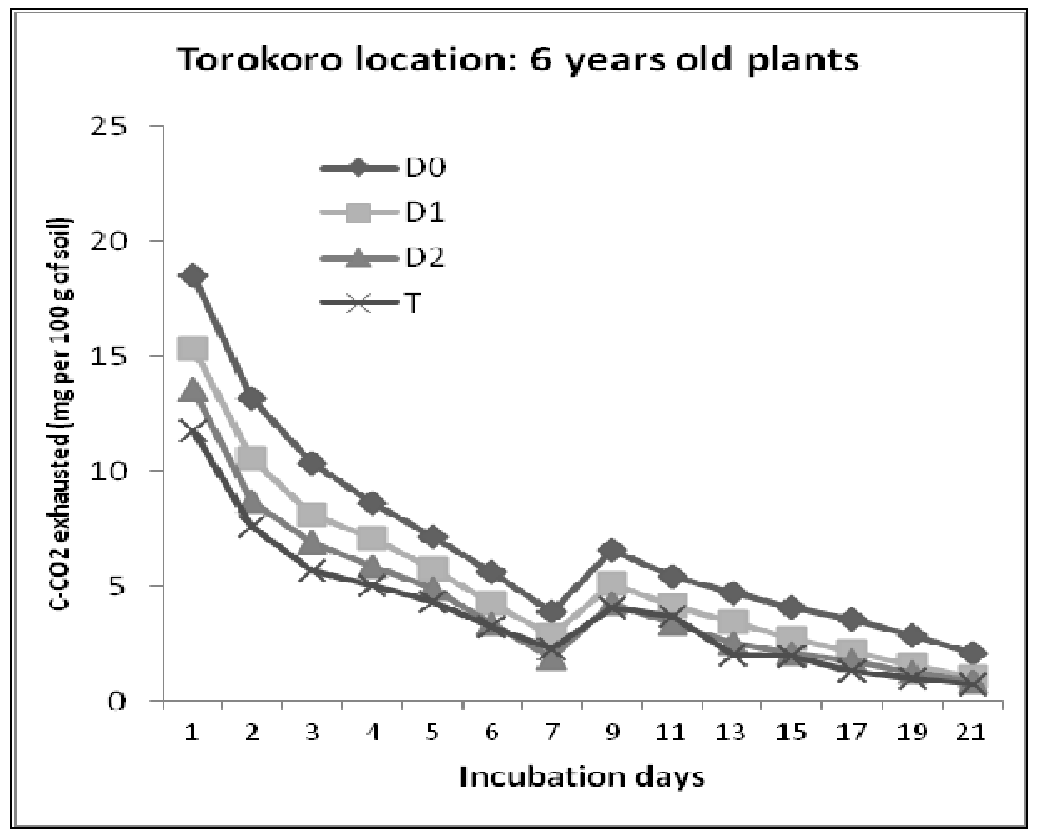

Figure 4: $\mathrm{CO}_{2}$ evolution during 21 days in Torokoro (Plantation 6 years). $\mathrm{D} 2=2 \mathrm{~m}$ from the crown of the tree

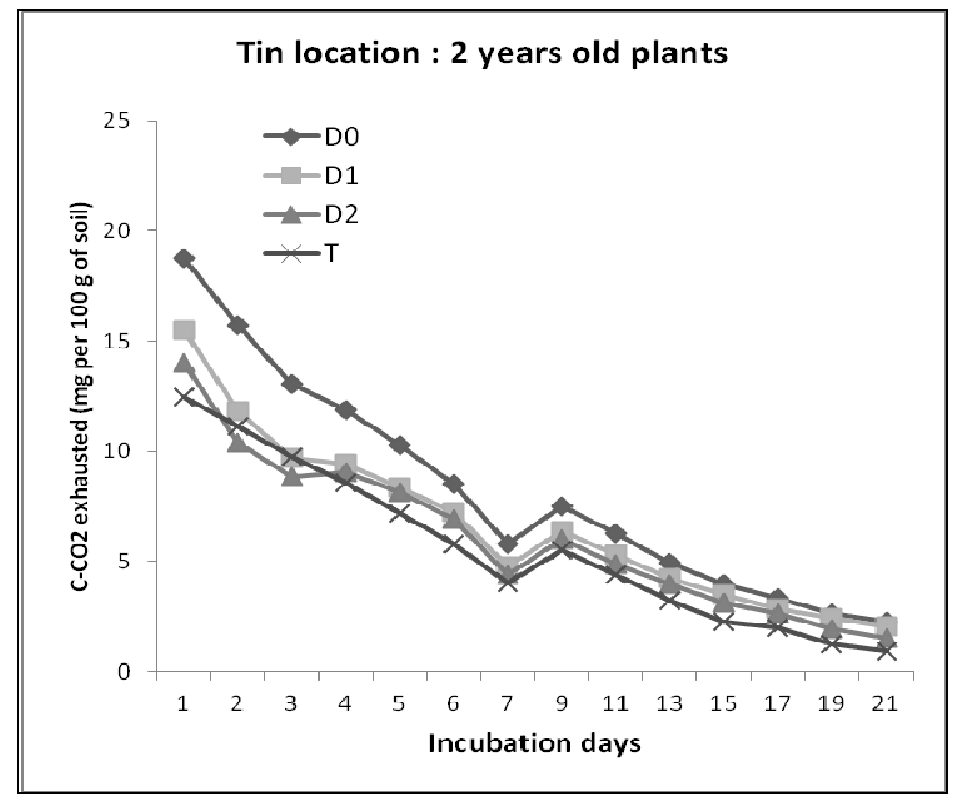

Figure 5: $\mathrm{CO}_{2}$ evolution during 21 days in Tin (Plantation 2 years). D0= under the crown, $\mathrm{D} 1=1 \mathrm{~m}$ from the crown of the tree, $\mathrm{T}=$ control (field without Jatropha) 


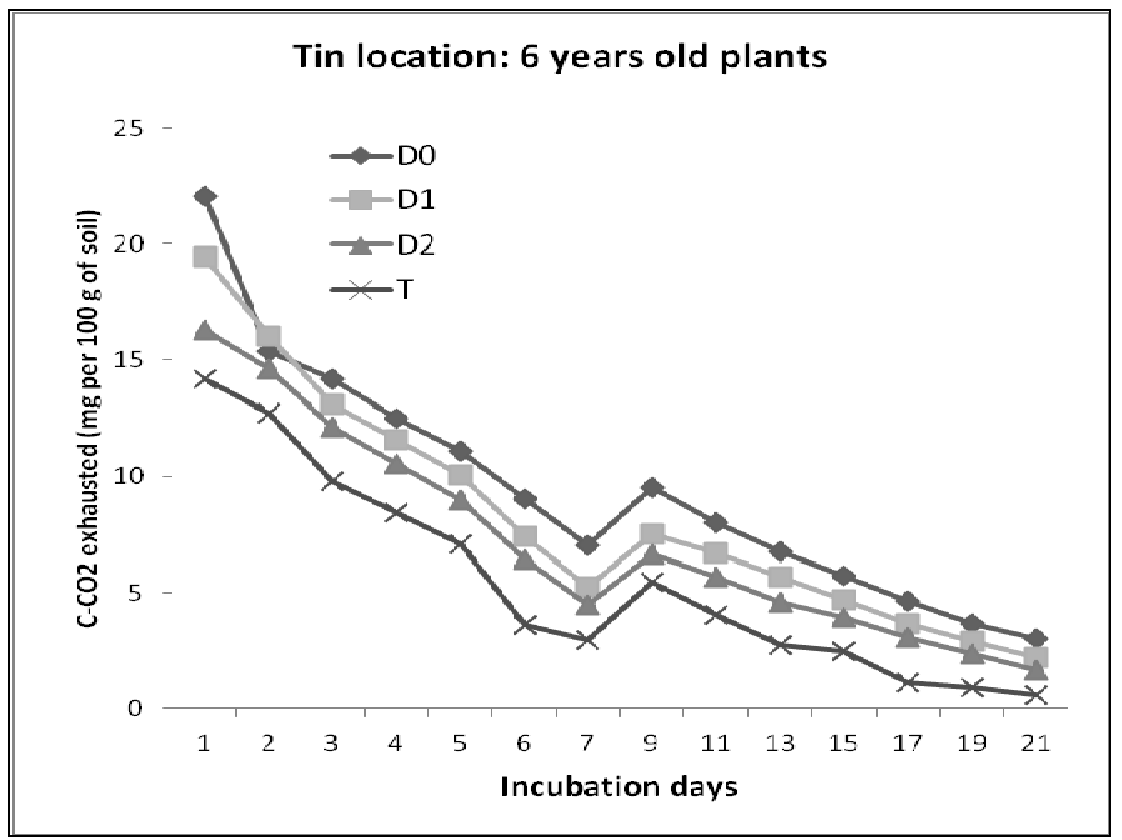

Figure 6: $\mathrm{CO}_{2}$ evolution during 21 days in Tin (Plantation 6 years). $\mathrm{D} 2=2 \mathrm{~m}$ from the crown of the tree

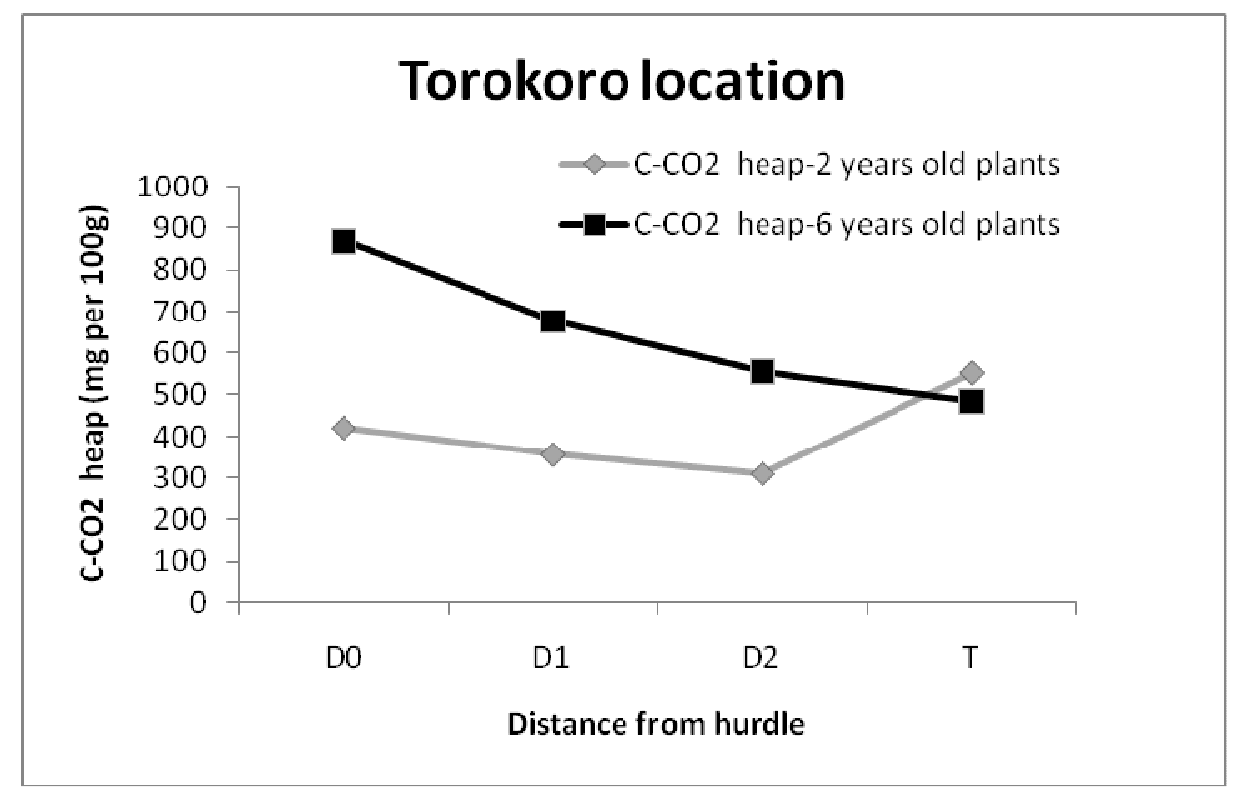

Figure 7: Cumulative C- $\mathrm{CO}_{2}$ in Torokoro. 


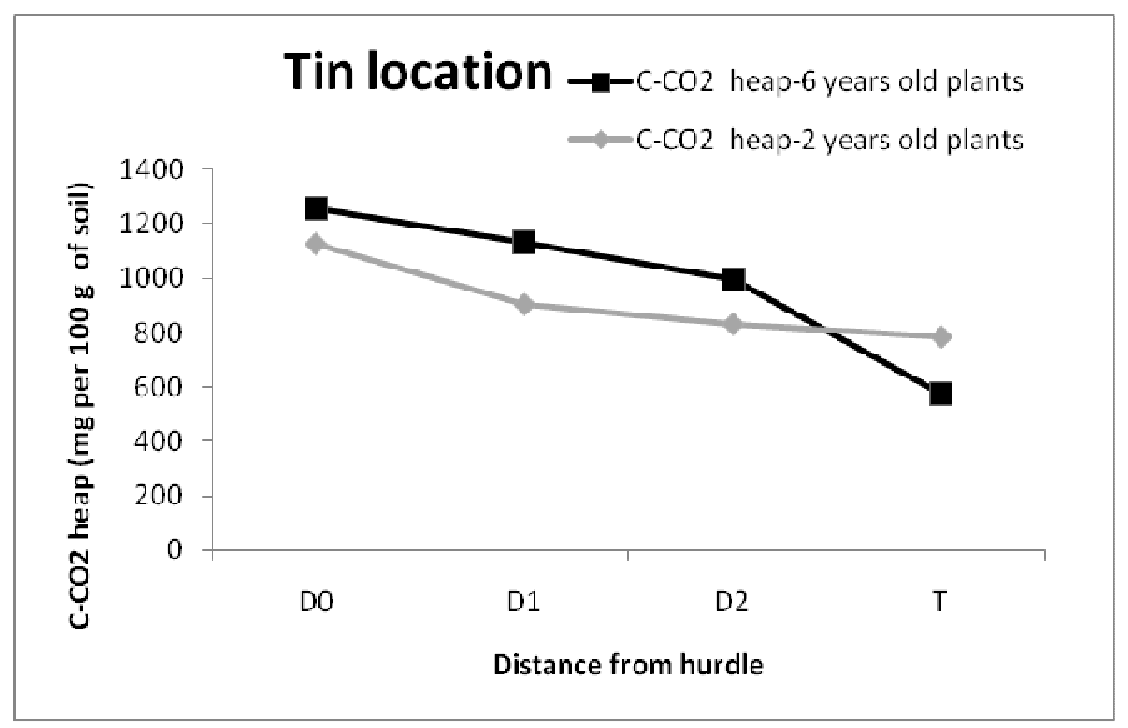

Figure 8: Cumulative $\mathrm{C}-\mathrm{CO}_{2}$ in Tin.

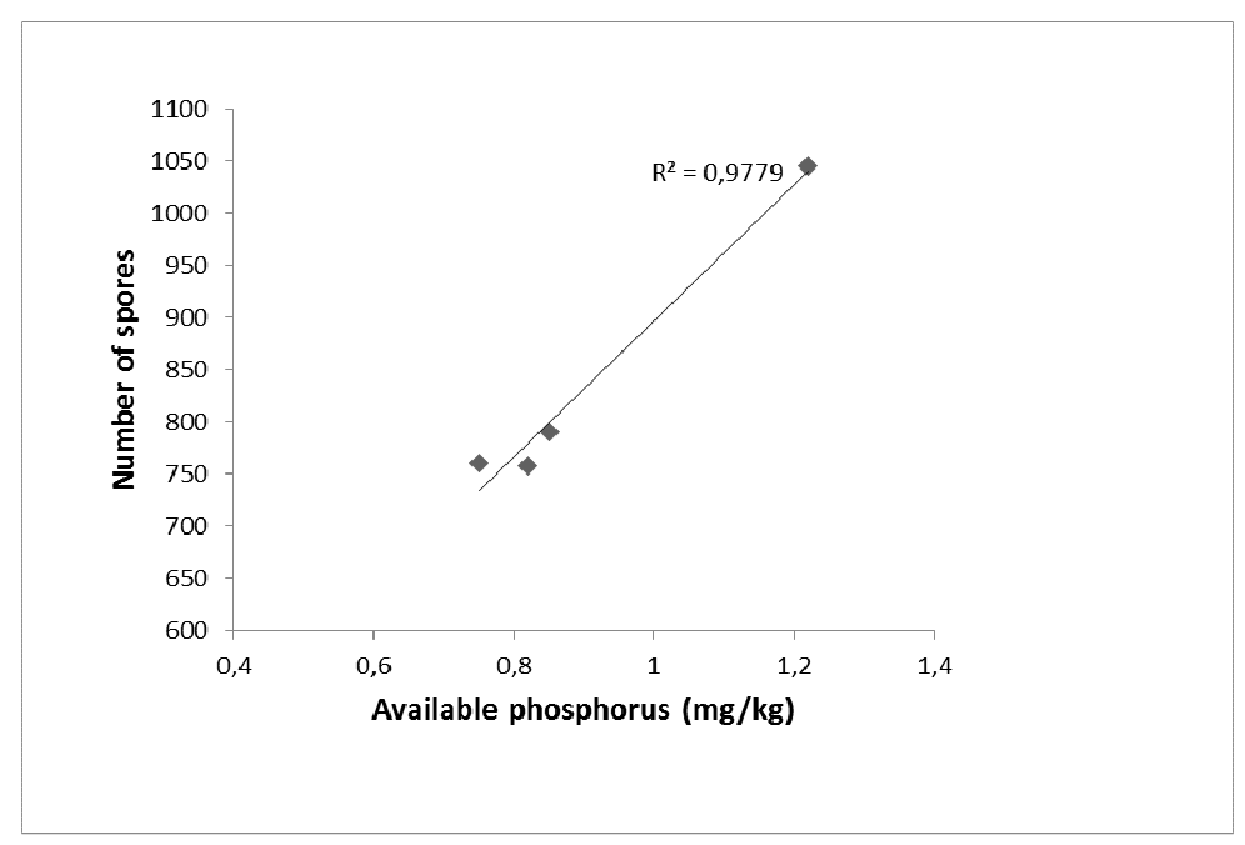

Figure 9: Relationship between available $\mathrm{P}$ and microbial biomass on the site of Torokoro. 


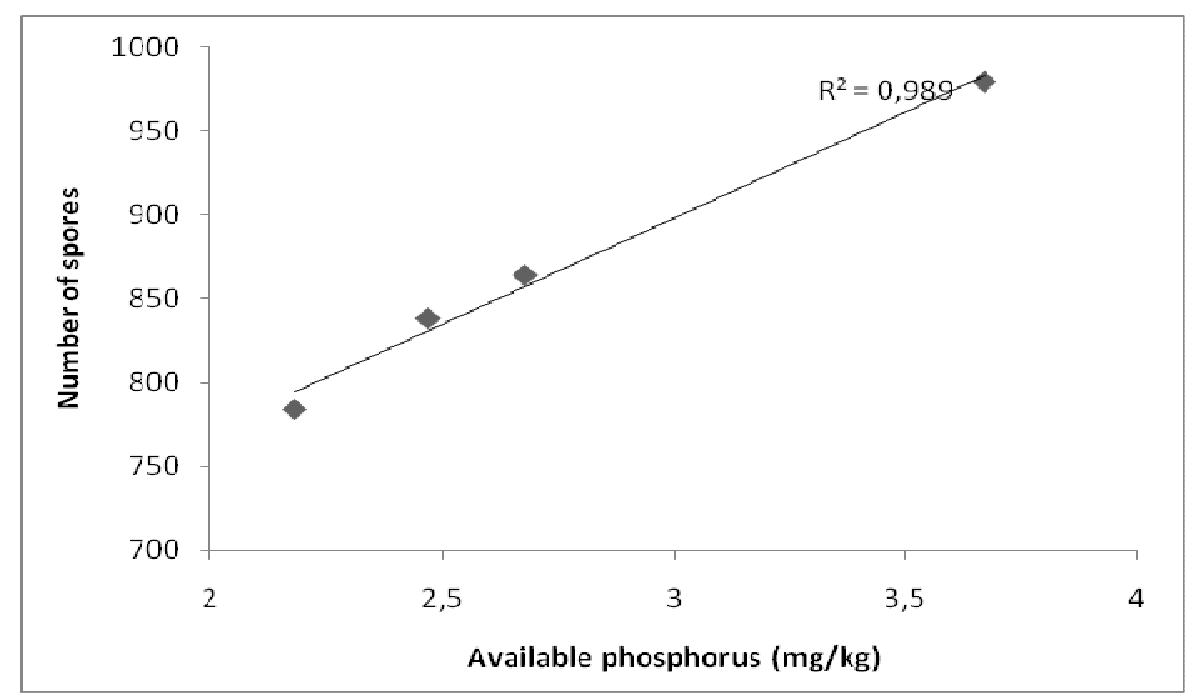

Figure 10: Relationship between available $\mathrm{P}$ and spores density on the Tin site.

Table 1 : Soil chemical properties as a function of distance from the crown of Jatropha (Torokoro, 2013).

\begin{tabular}{|c|c|c|c|c|c|c|}
\hline & & & \multicolumn{4}{|c|}{ Soils chemical parameters } \\
\hline Site & \multicolumn{2}{|c|}{ Treatments } & pH & OM (\%) & Total N (\%) & Av P(mg.kg $\left.{ }^{-1}\right)$ \\
\hline \multirow{12}{*}{ Tororokoro } & \multirow{4}{*}{$\begin{array}{l}2 \text { years old } \\
\text { plants }\end{array}$} & D0 & $6.83 \pm 0.49^{\mathrm{A}}$ & $1.56 \pm 0.22^{\mathrm{B}}$ & $0.05 \pm 0.01^{\mathrm{A}}$ & $3.65 \pm 0.36^{\mathrm{A}}$ \\
\hline & & D1 & $6.75 \pm 0.43^{\mathrm{A}}$ & $1.21 \pm 0.46^{\mathrm{C}}$ & $0.04 \pm 0.02^{\mathrm{A}}$ & $3.14 \pm 0.59^{\mathrm{B}}$ \\
\hline & & D2 & $6.61 \pm 0.28^{\mathrm{A}}$ & $1.19 \pm 0.45^{\mathrm{C}}$ & $0.04 \pm 0.02^{\mathrm{A}}$ & $3.15 \pm 1.70^{\mathrm{B}}$ \\
\hline & & $\mathrm{T}$ & $6.24 \pm 0.02^{\mathrm{B}}$ & $1.87 \pm 0.16^{\mathrm{A}}$ & $0.06 \pm 0.01^{\mathrm{A}}$ & $3.66 \pm 0.13^{\mathrm{A}}$ \\
\hline & \multicolumn{2}{|l|}{$\operatorname{Pr}>F$} & 0,000 & $<0,0001$ & 0,112 & 0,000 \\
\hline & \multicolumn{2}{|c|}{ Significance } & $S$ & $H S$ & $N S$ & $S$ \\
\hline & \multirow{4}{*}{$\begin{array}{l}6 \text { years old } \\
\text { plants }\end{array}$} & D0 & $6.20 \pm 0.28^{\mathrm{A}}$ & $0.86 \pm 0.18^{\mathrm{B}}$ & $0.04 \pm 0.02^{\mathrm{A}}$ & $0.75 \pm 0.14^{\mathrm{B}}$ \\
\hline & & D1 & $6.10 \pm 0.20^{\mathrm{AB}}$ & $0.75 \pm 0.12^{\mathrm{B}}$ & $0.04 \pm 0.02^{\mathrm{A}}$ & $0.82 \pm 0.19^{\mathrm{B}}$ \\
\hline & & D2 & $6.03 \pm 0.16^{\mathrm{AB}}$ & $0.75 \pm 0.09^{\mathrm{B}}$ & $0.03 \pm 0.02^{\mathrm{A}}$ & $0.85 \pm 0.19^{\mathrm{B}}$ \\
\hline & & $\mathrm{T}$ & $5.87 \pm 0.48^{\mathrm{B}}$ & $1.25 \pm 0.36^{\mathrm{A}}$ & $0.03 \pm 0.02^{\mathrm{A}}$ & $1.22 \pm 0.76^{\mathrm{A}}$ \\
\hline & \multicolumn{2}{|l|}{$\operatorname{Pr}>F$} & 0,021 & 0,001 & 0,441 & 0,002 \\
\hline & \multicolumn{2}{|c|}{ Significance } & $S$ & $S$ & $N S$ & $S$ \\
\hline
\end{tabular}

Numbers followed by the same letters are not significantly different at probability level of $5 \%$ according to the Newman Keuls test. D0= under the crown, D1= $1 \mathrm{~m}$ from the crown of the tree, D2= $2 \mathrm{~m}$ from the crown of the tree $\mathrm{T}=$ control (field without Jatropha). Av P = Available phosphorus. 
Table 2: Soil chemical properties as a function of distance from the crown of Jatropha (Tin, 2013).

\begin{tabular}{|c|c|c|c|c|c|c|}
\hline & & & \multicolumn{4}{|c|}{ Soils chemical parameters } \\
\hline Site & Treatments & & pH & OM (\%) & Total N (\%) & Av $\mathbf{P}\left(\mathrm{mg} \mathrm{kg}^{-1}\right)$ \\
\hline \multirow{12}{*}{ Tin } & & D0 & $6.47 \pm 0.19^{\mathrm{A}}$ & $0.81 \pm 0.39^{\mathrm{B}}$ & $0.03 \pm 0.01^{\mathrm{A}}$ & $0.77 \pm 0.26^{\mathrm{B}}$ \\
\hline & 2 years old & D1 & $6.52 \pm 0.23^{\mathrm{A}}$ & $0.77 \pm 0.23^{\mathrm{B}}$ & $0.03 \pm 0.01^{\mathrm{A}}$ & $0.75 \pm 0.11^{\mathrm{B}}$ \\
\hline & plants & $\mathrm{D} 2$ & $6.48 \pm 0.21^{\mathrm{A}}$ & $0.65 \pm 0.16^{\mathrm{B}}$ & $0.02 \pm 0.00^{\mathrm{A}}$ & $0.72 \pm 0.23^{\mathrm{B}}$ \\
\hline & & $\mathrm{T}$ & $6.27 \pm 0.08^{\mathrm{A}}$ & $1.37 \pm 0.15^{\mathrm{A}}$ & $0.04 \pm 0.00^{\mathrm{A}}$ & $1.53 \pm 0.16^{\mathrm{A}}$ \\
\hline & $P r>F$ & & 0,059 & $<0,0001$ & 0,193 & $<0,0001$ \\
\hline & Signicance & & $N S$ & $H S$ & $N S$ & $H S$ \\
\hline & \multirow{4}{*}{$\begin{array}{l}6 \text { years old } \\
\text { plants }\end{array}$} & D0 & $6.95 \pm 0.31^{\mathrm{A}}$ & $2.13 \pm 0.66^{\mathrm{A}}$ & $0.09 \pm 0.04^{\mathrm{A}}$ & $2.68 \pm 0.75^{\mathrm{B}}$ \\
\hline & & D1 & $6.54 \pm 0.42^{\mathrm{B}}$ & $1.94 \pm 0.89^{\mathrm{B}}$ & $0.07 \pm 0.04^{\mathrm{A}}$ & $2.47 \pm 0.70^{\mathrm{C}}$ \\
\hline & & D2 & $6.24 \pm 0.28^{C}$ & $1.81 \pm 0.69^{\mathrm{B}}$ & $0.07 \pm 0.03^{\mathrm{A}}$ & $2.18 \pm 0.77^{\mathrm{D}}$ \\
\hline & & $\mathrm{T}$ & $6.81 \pm 0.07^{\mathrm{A}}$ & $1.85 \pm 0.51^{\mathrm{B}}$ & $0.07 \pm 0.02^{\mathrm{A}}$ & $3.67 \pm 0.34^{\mathrm{A}}$ \\
\hline & $P r>F$ & & 0,000 & 0,018 & 0,095 & 0,002 \\
\hline & Significance & & $S$ & $S$ & $N S$ & $S$ \\
\hline
\end{tabular}

Numbers followed by the same letters are not significantly different at probability level of 5\% according to the Newman Keuls test. $\mathrm{D} 0=$ under the crown, $\mathrm{D} 1=1 \mathrm{~m}$ from the crown of the tree, $\mathrm{D} 2=2 \mathrm{~m}$ from the crown of the tree $\mathrm{T}=\mathrm{control}(\mathrm{field}$ without Jatropha), Av P = Available phosphorus

Table 3 : Change in the microbial biomass of the soil under cultivation of Jatropha at Torokoro and Tin locations.

\begin{tabular}{lcccc}
\hline \multicolumn{5}{c}{ Microbial biomass (mg per 100 g of soil) } \\
\hline Treatments & Torokoro-2 years & Torokoro-6 years & Tin-2 years & Tin-6 years \\
\hline D0 & $59.26 \pm 9.10^{\mathrm{A}}$ & $63.30 \pm 7.05^{\mathrm{A}}$ & $69.35 \pm 22.65^{\mathrm{A}}$ & $224.71 \pm 27.13^{\mathrm{A}}$ \\
$\mathrm{D} 1$ & $50.02 \pm 8.59^{\mathrm{C}}$ & $55.93 \pm 6.11^{\mathrm{B}}$ & $63.32 \pm 21.30^{\mathrm{B}}$ & $198.18 \pm 39.20^{\mathrm{C}}$ \\
$\mathrm{D} 2$ & $43.88 \pm 7.05^{\mathrm{D}}$ & $50.82 \pm 5.19^{\mathrm{C}}$ & $56.21 \pm 13.98^{\mathrm{C}}$ & $208.49 \pm 17.24^{\mathrm{B}}$ \\
$\mathrm{T}$ & $53.53 \pm 2.39^{\mathrm{B}}$ & $44.90 \pm 2.35^{\mathrm{D}}$ & $42.20 \pm 1.25^{\mathrm{D}}$ & $147.83 \pm 1.56^{\mathrm{D}}$ \\
Pr $>$ F & $<\mathbf{0 , 0 0 0 1}$ & $<\mathbf{0 , 0 0 0 1}$ & $<\mathbf{0 , 0 0 0 1}$ & $<\mathbf{0 , 0 0 0 1}$ \\
Significance & $\boldsymbol{H} \boldsymbol{S}$ & $\boldsymbol{H} \boldsymbol{H}$ & $\boldsymbol{H} \boldsymbol{H}$ & $\boldsymbol{H}$ \\
\hline
\end{tabular}

Numbers followed by the same letters are not significantly different at probability level of 5\% according to the Newman Keuls test. $\mathrm{D} 0=$ under the crown, $\mathrm{D} 1=1 \mathrm{~m}$ from the crown of the tree, $\mathrm{D} 3=2 \mathrm{~m}$ from the crown of the tree $\mathrm{T}=$ control (field without Jatropha); HS=highly significant.

Table 4: Density of Arbuscular Mycorrhizal Fungal spores in land under cultivation of Jatropha.

\begin{tabular}{lcccc}
\hline \multicolumn{5}{c}{ Spores density (per 100 g of dry soil) } \\
\hline Treatments & Torokoro-2 years & Torokoro-6 years & Tin-2 years & Tin-6 years \\
\hline D0 & $760.44 \pm 223.08^{\mathrm{C}}$ & $901.55 \pm 162.69^{\mathrm{B}}$ & $814.44 \pm 211.95^{\mathrm{B}}$ & $864.44 \pm 216.98^{\mathrm{B}}$ \\
$\mathrm{D} 1$ & $758.11 \pm 185.20^{\mathrm{C}}$ & $869.22 \pm 135.84^{\mathrm{C}}$ & $796.33 \pm 82.93^{\mathrm{D}}$ & $838.66 \pm 288.15^{\mathrm{C}}$ \\
$\mathrm{D} 2$ & $789.66 \pm 180.04^{\mathrm{B}}$ & $845.22 \pm 281.71^{\mathrm{D}}$ & $798.88 \pm 247.88^{\mathrm{C}}$ & $784.44 \pm 262.07^{\mathrm{D}}$ \\
$\mathrm{T}$ & $1046 \pm 53.39^{\mathrm{A}}$ & $994.66 \pm 169^{\mathrm{A}}$ & $1063.33 \pm 25.32^{\mathrm{A}}$ & $979.33 \pm 125.42^{\mathrm{A}}$ \\
$\boldsymbol{P r}>\boldsymbol{F}$ & $<\mathbf{0 , 0 0 0 1}$ & $<\mathbf{0 , 0 0 0 1}$ & $<\mathbf{0 , 0 0 0 1}$ & $<\mathbf{0 , 0 0 0 1}$ \\
Significance & $\boldsymbol{H S}$ & $\boldsymbol{H S}$ & $\boldsymbol{H S}$ & $\boldsymbol{H S}$ \\
\hline
\end{tabular}

Numbers followed by the same letters are not significantly different at probability level of 5\% according to the Newman Keuls test. D0= under the crown, D1= $1 \mathrm{~m}$ from the crown of the tree, D2 $=2 \mathrm{~m}$ from the crown of the tree $\mathrm{T}=$ control (field without Jatropha). 
Table 5: Relationship between chemical and biological parameters on the site of Torokoro.

\begin{tabular}{|c|c|c|c|}
\hline \multicolumn{4}{|c|}{ Matrix (Pearson correlation coefficient) } \\
\hline & C-CO2 exhausted & Microbial Biomass & Spore number \\
\hline $\mathrm{pH}\left(\mathrm{H}_{2} \mathrm{O}\right)$ & 0.461 & 0.981 & -0.081 \\
\hline $\mathrm{pH}(\mathrm{KCl})$ & 0.461 & 0.978 & -0.073 \\
\hline Total $\mathrm{N}$ & 0.421 & 0.900 & -0.099 \\
\hline total C & 0.430 & 0.909 & -0.047 \\
\hline $\mathrm{OM}$ & 0.430 & 0.909 & -0.047 \\
\hline $\mathrm{C} / \mathrm{N}$ & 0.299 & 0.625 & 0.002 \\
\hline total $\mathrm{P}$ & -0.408 & -0.861 & 0.037 \\
\hline Total K (g/kg) & -0.460 & -0.976 & 0.071 \\
\hline Av $\mathrm{P}$ & 0.778 & -0.005 & 0.989 \\
\hline
\end{tabular}

N: Nitrogen, C: Carbon, OM: Organic Mater, K: Potasium, Av P: Available Phosphorus.

Table 6: Relationship between chemical and biological parameters on the Tin site.

\begin{tabular}{lccc}
\hline & Matrix (Pearson correlation coefficient): & \\
\hline & C-CO2 exhausted & Microbial Biomass & Spore number \\
\hline $\mathrm{pH}\left(\mathrm{H}_{2} \mathrm{O}\right)$ & 0.955 & 0.882 & -0.561 \\
$\mathrm{pH}(\mathrm{KCl})$ & 0.873 & 0.961 & -0.718 \\
Total N & 0.673 & 0.996 & -0.892 \\
Total C & 0.689 & 0.995 & -0.878 \\
$\mathrm{OM}$ & 0.689 & 0.995 & -0.878 \\
$\mathrm{C} / \mathrm{N}$ & 0.998 & 0.745 & -0.346 \\
Total P & 0.642 & 0.994 & -0.908 \\
Total K $(\mathrm{g} / \mathrm{kg})$ & 0.644 & 0.995 & -0.910 \\
Av P & -0.363 & -0.918 & 0.995 \\
\hline
\end{tabular}

N: Nitrogen, C: Carbon, OM: Organic Matter, K: Potasium, Av P: Available Phosphorus.

\section{DISCUSSION}

The chemical properties of soils under Jatropha

The results obtained showed no significant impact of Jatropha plantation on soil $\mathrm{pH}$ in the two sites. This is similar to those obtained by Diedhiou et al. (2009) and Sanou (2010) who found that Jatropha does not acidify the soil under its culture. The level of organic matter found in Jatropha fields is higher than the standard value $(0.5 \%)$. Jatropha fields were fallow fields before Jatropha was planted. These results indicated that the farmers are using their unexploited land to plant Jatropha without disturbing their food crop production. The results showed deficient soils nitrogen for all locations and distances. Jatropha trees seem to have an impact on soil nitrogen (Legendre, 2008). Soil $\mathrm{P}$ availability is very low and all the soil are deficient in available $\mathrm{P}(<5 \mathrm{mg} / \mathrm{kg})$. This can be linked to the low nitrogen proportion and $\mathrm{pH}$ of soil which are not favorable to soil $\mathrm{P}$ absorption. The results from Torokoro show a retention of P under Jatropha trees which is probably due to the formation of clay-humic complexes in the soil under the Jatropha trees. These results are the same as those of 
Sanou (2010) presenting the influence of the crown of Jatropha on the variation of the available $\mathrm{P}$ content.

\section{The biological properties}

The quantity of $\mathrm{CO}_{2}$ release is a function of the organic matter, nitrogen and phosphorus content of the soils (Zombré, 2006). The daily evolution of the $\mathrm{CO}_{2}$ is in connection with results obtained by different authors (Zombré, 2006; Yélémou, 2010). The high activity of the early days of incubation reflects the existence of carbonaceous substances easily mineralisable. These are dead microorganisms during the preparation of the samples and of labile compounds such as sugars and proteins. The decrease of microbial activity is a result of depletion of micro- organism food reserves in the soil. But a clear difference remains between soils under crown, $1 \mathrm{~m}$ and $2 \mathrm{~m}$ from crown. Zombré. (2006) also found on bare crust lower biological activity representing just only one fifth $(1 / 5)$ of the activity of vegetated areas. The positive correlation between $\mathrm{C}-\mathrm{CO}_{2}$ and organic matter content of soils on sites supports these findings and corroborate with the findings of Lavelle et al. (2006) and Rombké et al. (2006) on the linear relationship between the organic content of the soil and its biological activity.

The rhizodeposits are essentially made of roots exudates and enzymes (Gobat et al., 2010) among many plant species. These substances may have stimulatory effects of microbial activity and could also explain the respiratory intensity in the rhizosphere of Jatropha. Somé et al. (2007) argue that nutrient transfers of the aerial part to underground parts, rhizodeposition and metabolizable addition of new products would stimulate bacterial activity; which would increase the microbial population with a larger mineralizing action.

In addition, microbial biomass evaluated on these two sites show a decrease with distance from the crown. The same observation was made by Yélémou (2010) under Piliostigma reticulatum whatever in different phytogeographic zones. The soil microbial biomass is the mineralizable fraction of the organic matter. ITAB (2002) and Girard et al. (2011) have evaluated respectively 2-4\% and 1-3\% organic matter in different soils. ITAB (2002) and Zombré (2006) found a correlation between these variables. The mycorrhizal spores density of the two sites is acceptable (> 1500 propagule.kg - 1) according to ITAB (2002). These results are good indicators for soils biological qualities. Various factors influence the populations of AMF and the development of symbiosis. Among these factors we can mention $\mathrm{pH}, \quad \mathrm{P}$ bioavailability, dry environments or engorged and soil type (Mure, 2005; Asimi, 2009). pH seems to have little effect when it is between 5.5 and 7.5 (Mure, 2005), which is the case for all plantations in the two sites. For P, high levels of mycorrhization were observed in cases of low or high levels contents, but it seems that the effectiveness of symbiosis is even greater when $\mathrm{P}$ concentration in the soil solution is low and the fixing capacity of soil is high (Mure, 2005). In our case, low levels of available $\mathrm{P}$ recorded at different sampling points $\left(0.72\right.$ to $\left.3.67 \mathrm{mg} . \mathrm{kg}^{-1}\right)$ didn't affect the density of spores. The abundance of spores at the crown could be explained by the high density of fine roots of Jatropha (headquarters of mycorrhizae formation) at this level.

Soils chemical properties under the crown being the best, we have a good expression of mycorrhizae at these levels to meet the nutrients needs of the plants. The positive effect of the improvement of soil $\mathrm{pH}$ on mycorrhization was also highlighted by ITAB (2002). However, the excessive level of nutrients including phosphorus and nitrogen is a limiting factor for mycorrhiza (ITAB, 2002; Asimi, 2009). 


\section{Conclusion}

From the current study, we can draw the following conclusions. The chemical properties of soils vary depending on the distance from the crown of Jatropha. Soils $\mathrm{pH}, \mathrm{OM}$ and the total $\mathrm{N}$ are higher under the crown, and decreased gradually to $2 \mathrm{~m}$ from the tree. Soil available phosphorus increased with distance from the crown in Torokoro but the opposite situation is found in Tin. The biological properties of soils varied depending on the distance. The biological activity and microbial biomass were more intense under the crown and declined onward for all sites. The endomycorhizal spores density remains bounded to the nutrients availability of the location, strong correlation was observed between the chemical and biological properties and the number of spores increased with the available of $\mathrm{P}$ in the soil. Our study was a contribution to the knowledge of Jatropha farming in Burkina and we recommend following up with the identification of the different types of microorganisms developed under Jatropha trees.

\section{AKNOWLEDGMENTS}

The authors are grateful to the Laboratory of Chemistry and Microbiology of INERA- Farako-Ba and Kamboinse for technical assistance in chemical and biological analysis.

\section{COMPETING INTEREST}

The authors declare that they have no competing interests.

\section{AUTHORS' CONTRIBUTIONS}

PB conducted the study on the field, collected and analyzed data, and wrote the manuscript; KT oriented the study and corrected the manuscript; KBS played an important role in the correction of biological issues in the manuscript; BY, OT, BHN, BB, MT, VH and MPS corrected the manuscript; MB Helped us in data collection.

\section{REFERENCES}

Achten, WMJ, Maes WH, Aerts R, Verchot L, Trabucco A, Mathijs E, Singh, VP, Muys B. 2010a. Jatropha From global hype to local opportunity. Journal of Arid Environments, 74: 164-165.

Asimi S. 2009. Influence des modes de gestion de la fertilité des sols sur l'activité microbienne dans un système de cultures de longue durée au Burkina Faso. Thèse de Doctorat d'état èssciences naturelles, Institut du Développement Rural/ Université Polytechnique de Bobo-Dioulasso, p. 177.

Baumert S. 2010. Jatropha curcas: Sustainable biofuel production in Burkina Faso? Carbon and Energy balance and Economic costs and benefits as sustainability indicators. PhD-Thesis Proposal. ZEF, Bonn.

Béné A, Fournier A. 2014. Végétation Naturelle et occupation des terres au Burkina Faso (Afrique de l'Ouest). Cinq décennies de changement dans un terroir $\mathrm{du}$ pays Sèmè. Acte du colloque international de Ouagadougou, Sciencesconf.org, 143-164.

Blind J, Dabat M H, Faugere G, Hanff E, Weisman N. 2008. Opportunités de développement des biocarburants au Burkina Faso. Ministère de l'Agriculture, de l'Hydraulique et des Ressources Halieutiques, Ouagadougou, Burkina Faso, p. 57.

Brittaine R, Lutaladio N. 2010. Jatropha: A smallholder Bioenergy Crop. The Potential for Pro-Poor development. FAO, Vol. 8-2010, p. 114.

Brundett MC, L Melville, RL Peterson. 1994. Practical methods in mycorrhiza research. Mycological publication, Waterloo, Canada, p. 161.

BUNASOLS. 1986. Méthodes d'analyse physique et chimique des sols, eaux et plantes. BUNASOLS, Document technique $\mathrm{n}^{\circ}$ 3: 48-128. 
Chaussod R, Nicolardot B, Catroux G. 1986. Mesure en routine de la biomasse microbienne des sols par la méthode de fumigation au chloroforme. Science $d u$ Sol, 2: 201-211.

COMPETE. 2008. Sixth Framework Program FP6-2004-INCO-DEV-3 Priority A.2.3.: Managing Arid and Semi-arid Ecosystems. Competence Platform on Energy Crop and Agroforestry Systems for Arid and Semi-arid Ecosystems - Africa (COMPETE). Available online: http://www.compete-bioafrica.net.

Dickman SR, Bray HR. 1940. Colorimetric determination of phosphate. Ind. Eng. Chem, Anal. Ed., 12: 665-668.

Diédhiou I. 2009. Impacts potentiels de l'introduction de Jatropha curcas L; dans un contexte de variabilité et changement climatiques: impacts agricoles et environnementaux, intérêts économiques pour les ménages et communautés rurales. Atelier de clôture RIPIECSA, Cotonou, Bénin, 18-21 octobre. Université de Thiès, Sénégal.

Endelevu E. 2009. Jatropha Reality Check: A field assessment of the agronomic and economic viability of Jatropha and other oilseed crops in Kenya, p 27.

FAO. 2010. Jatropha: A Smallholder Bioenergy Crop. The Potential for ProPoor Development. Brittaine R, Lutaladio N. Integrated Crop Management Vol. 8-2010. Rome.

Hallensleben M. 2011. Assessment of Jatropha curcas Systems and their Potential for Rural Development in Burkina Faso, West Africa; Master Thesis of Science; Faculty of Agriculture Rheinische FriedrichWilhelms-Universität zu Bonn, p. 201.

Hillebrand WF, GEF Lundell, Bright HA, Hoffman JI. 1953. Applied inorganic analysis, 2nd ed. John Wiley, Sons, Inc., New York, USA, p. 1034.

Gerdmann JW, Nicolson TH. 1963. Spores of mycorrhizal Endogone species extracted from soil by wet sieving and decanting.Trans.Br. Mycol. Soc., 46: 235-244.

Girard M C, Walter C, Rémy J C, Berthelin J, Morel J 1. 2011. Sol et environnement, 2ème édition, DUNOD, 61-864.

Gobat JM, Arago M, Matthey W. 2010. Le sol vivant: Base de Pédologie - Biologie des sols. Presse polytechniques et universitaires Romanes, $3^{\mathrm{e}}$ édition, 1146.

ITAB. 2002. Activités biologiques et fertilité des sols: Intérêts et limites des méthodes analytiques disponibles, p. 25.

Mure JP. 2005. Mycorrhizal symbiosis: a beneficial association between cultivated plants and soil fungi. Alter Agri., 69: 25-28.

Laviola BG, Dias LAS. 2008. Nutrient concentration in Jatropha curcas leaves and fruits and estimated extraction at harvest. R. Bras. Ci. Solo, 32:19691975.

Legendre B. 2008. Jatropha curcas (Tabanani). Note agronomique. Technologies for Human development, p. 8.

Lavelle P, Decaens M, Aubert M, Barot S, Bloiun M, Bureau F, Magerie P, Mora P, Rossi J P. 2006. Soil invertebrates and ecosystem services. European Journal of Soil Biology, 42(1): S3-S15.

Leye EHM, Ndiaye M, Ndiaye F, Diallo B, Sarr AS, Diouf M, Diop T. 2009. Effet de la mycorhization sur la croissance et le développement de Jatropha curcas L. Revue des Energies Renouvelables, 12(2): 269- 278.

Lottmann JH. 2008. Lessons to be learned for Tunisia from the cultivation and utilization of Jatropha curcas Linné (JCL) worldwide. Word-doc.

Low T, Booth C. 2007. The weedy truth about Biofuels in Melbourne: the Invasive Species Council; 1-20.

Openshaw K. 2000. A review of Jatropha curcas: an oil plant of unfulfilled 
promise. Biomass and Bioenergy, 19(1): $1-15$.

Paramathma M, Venkatachalam P, Sampathrajan A. 2007. Jatropha Improvement, Management and Production of Biodiesel. Centre of Excellence in Biofuels Agricultural Engineering. Book on the application of practical knowledge in energy crops College and Research Institute, Tamil Nadu Agricultural University, and Coimbatore 641003, p. 262.

Reubens B, Achten, WMJ, Maes WH, Danjon F, Aerts R, Poesen J, Muys B. 2010. More than biofuel? Jatropha curcas root system symmetry and potential for soil erosion control. Journal of Arid Environments, 75: 201205

Rombké J, Sousa J P, Schouten T, Rieper T F. 2006. Monitoring of soil organisms: a set of standardized field methods proposed by ISO. European Journal of Soil Biology, 42(1): S61-S63.

Sreedevi TK, Wani SP, Rao S, Chaliganti R, Reddy RL. 2009. Jatropha and Pongamia rainfed plantations on Wastelands in India for Improved Livelihoods and Protecting Environment. International Crops Research Institute for the semi-arid Tropics, (ICRISAT), Patancheru PO. Patancheru, 502 324, India.

Sanou F. 2010. Productivité de Jatropha curcas L. et impact de la plante sur les propriétés chimiques du sol: cas de Bagré (Centre Est du Burkina Faso. Mémoire de fin de cycle, Université. Polytechnique de Bobo-Dioulasso, p. 55.

Somé N A, Traoré K, Tassembedo M. 2007. Potentiel des jachères artificielles à Andropogon spp dans l'amélioration des propriétés chimiques et biologiques des sols en zone soudanienne (Burkina
Faso). Biotechnol. Agron. Soc. Environ., 11(3): 245-252.

Thiombiano L, Dianou D. 1999. Activité biologique globale dans trois états de surface des sols sahéliens. A.U.O, série $B$ VII : 179-187.

Traoré K. 2009. Synthèse Bibliographique sur le Jatropha curcas à l'Ouest du Burkina. Institut de l'Environnement et de Recherche Agricole. Rapport d'activités. Burkina Faso, p. 8.

Walkley A, Black RN. 1934. An examination of the method Dedtjareff for determining soil organic matter and to proposed modification of the chromic acid titration method. Soil Science, 37: 29-38.

Wu J, RG Joergensen, Pom BR, Chaussod PC Brookes. 1990. Measurement of soil microbial biomass $\mathrm{C}$ by fumigation extraction - An automated procedure. Soil Biol. Biochem., 22: 1167-1169.

Yélémou B. 2010. Biologie et écologie des espèces du genre Piliostigma et leur contribution à la dynamique de la matière organique des sols en zone sahélo-soudanienne au Burkina Faso, Thèse de Doctorat, Université de Ouagadougou, p. 150.

Youl S. 2009. Dynamique et modélisation de la dynamique du carbone dans un agrosystème de savane de l'ouest du Burkina Faso. Doctorat Unique, Institut du Développement Rural/ Université Polytechnique de Bobo-Dioulasso, p. 186.

Zombré N P. 2006. Variation de l'activité biologique dans les Zippella (sols nus) en zone subsahélienne du Burkina Faso et impact de la technique du zaï (technique des poquets). Biotechnol. Agron. Soc. Environ., 10(2): 139-148. 